\title{
LAMC2 wt Allele
}

National Cancer Institute

\section{Source}

National Cancer Institute. LAMC2 wt Allele. NCI Thesaurus. Code C116276.

Human LAMC2 wild-type allele is located within 1q25-q31 and is approximately 59 kb in length. This allele, which encodes laminin subunit gamma-2 protein, is involved in both the development of the epidermis and extracellular matrix organization. Mutation of the gene is associated with Herlitz junctional epidermolysis bullosa. 